\title{
Development of High School Students' Understanding and Confidence skills with VBA for Excel Shapes Games
}

\author{
$1^{\text {st }}$ Martin Bernard ${ }^{1}, 2^{\text {nd }} M$. Afrilianto ${ }^{2}, 3^{\text {rd }}$ Carilah $^{3}$ \\ \{Pamartin23rnard@gmail.com¹, Muhammadafrilianto1@gmail.com², carilahtarsono@yahoo.com³
}

IKIP Siliwangi, Bandung, Indonesia

\begin{abstract}
The purpose of this research is to see how many secondary school students develop their understanding and self-confidence about how to work and process statistical data through assisted game forms or rod image forms that are run using VBA for Microsoft Excel. it is given to 36 students who have various mathematical abilities. The method used is Classroom Action Research which consists of two cycles in statistical material. And obtained the results, it was found that the previous students had an average value of 41.80 with a standard standard of 1.81 and after the experiment the average value of 64.68 and standard standard 2.41. And after being processed using SPSS 22 for both data showed a significant value for the second difference on average less than 0.05 means that the effect of learning statistics before and after using Shapes games through VBA for Microsoft Excel.
\end{abstract}

Keywords: Ability of Mathematical Understanding, Self Confidence, VBA for Microsoft Excel.

\section{Introduction}

Mathematics is one part of science that plays an important role in developing other sciences with a form of size as a standard for increasing the results of activities in the management of science. Therefore, mathematics is always given to students at various levels, in accordance with Bernard's opinion [1], which states that mathematics debriefing is given to students since elementary school because in mathematics students have a logical, analytical, systematic, critical and creative thinking process. Statistics is one part of mathematics that has the aim of students having the ability to process data in the form of size and describing a problem of that size in a variety of events, not just based on the count because of their assumptions related to mathematics, this agrees with Koparan [2] which states that statistics not only for mathematics but how students make decisions and develop and are able to apply in various sciences. To bring creative ideas or ideas of students in developing science, of course, need mastery of basic knowledge related to statistics through the process of understanding abilities.

Understanding ability is one of the basics that must be mastered by students, before the ability of students to a higher level about statistics. The purpose of understanding skills, so that students are able to interpret statistical lessons from various information related to statistics [3]. However, some findings of the difficulties of understanding ability with the cause of students do not have the ability to explain, model or formulate and make steps in 
solving problems [4]. And this is in line with the results of Ramdhani's [5] research that low uptake in junior high school students at the regional, provincial and national levels for understanding abilities is below 50\% which affects high school, which is caused by lack of mastering mathematical concepts and definitions. From the findings of the difficulties there are several causes of students' difficulties in understanding abilities related to statistics, first, students are not able to clearly understand the definition of statistics, second, students have not been able to develop mathematical concepts so students can explain the steps in solving statistical problems, third make conclusions in the form of a formula based on students' observations in statistics. To overcome the difficulties of students' comprehension skills, researchers support students to form mathematical concepts in statistical learning with one of the mathematical media through computers, although they can also without using a computer [6], researchers make learning strategies that are able to collaborate between students and instructors, so that there are active learning and teaching in the classroom [7].

How to overcome the difficulty of the ability to understand students is the use of mathematics learning media in statistical materials. Of course, the designed media must be able to form mathematical concepts so that students easily understand statistics and raise students' self-confidence to explain the definition of statistics and be able to solve problems according to the steps understood by students. The purpose of mathematics learning media helps students to visualize from abstract forms to concrete forms, increase students' interest to bring up students' self-confidence, improve students' mathematical understanding ability and make the teaching and learning process in the classroom more interactive [8]

To help improve the ability of students' understanding and student confidence about statistics, it is necessary to have interactive mathematics learning media, the aim is to provide examples of images related to statistics so that students easily remember, which is also an advantage for teachers to make teaching material strategies in schools more interesting so students can easily complete statistics [9]. Of course, the media of mathematics learning must have various forms so that students do not get bored to learn statistics [10]. Therefore, the media used is ICT-based because it has the advantage of creating a student learning atmosphere that is more active and can be linked to the progress of the times. The software used for media creation can use VBA for Microsoft Excel and VBA for Powerpoint because this software is easily obtained and developed into mathematics games and mathematics learning media that can improve students' thinking skills [11]-[14]For statistical learning, good software is used in Microsoft Excel by utilizing mathematical functions more effectively by using Visual Basic Application for Microsoft Excel which is applied to the steps of the algorithm [15] which is able to create interesting and varied mathematics learning media.

\section{Research Method}

This study was a Classroom Action Research (CAR), which was a study intended to provide information on how appropriate actions are to improve teacher ability and student activity. Therefore, this study focuses on actions as an appropriate effort to improve teachers 'ability to teach and increase students' mathematical understanding, especially in mathematics learning. 


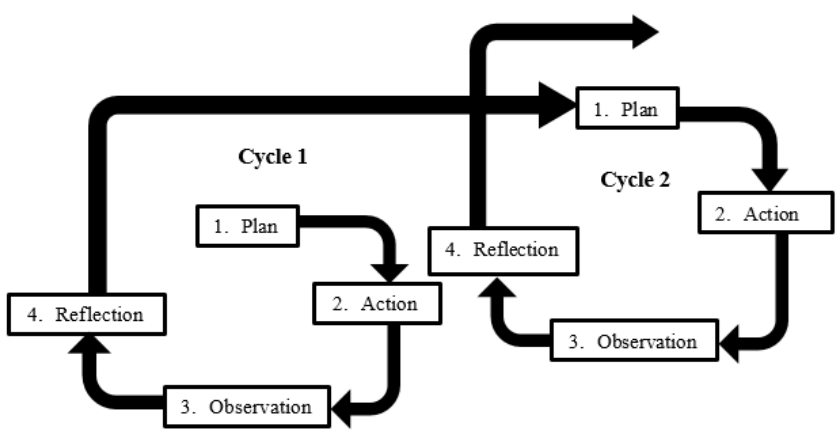

Fig. 1. Classroom Action Research Model

The above model is a general model of action research. Often known as Spiral Research Actions based on Kemmis [16] are as follows:

1. In Cycle I consists of:
a. Plans;
b. Action;
c. Observation;
d. Reflection.

2. In Cycle II consists of:
a. a new plan;
b. Action;
c. Observation;
d. Reflection.

Finish or continue to cycle III, and so on.

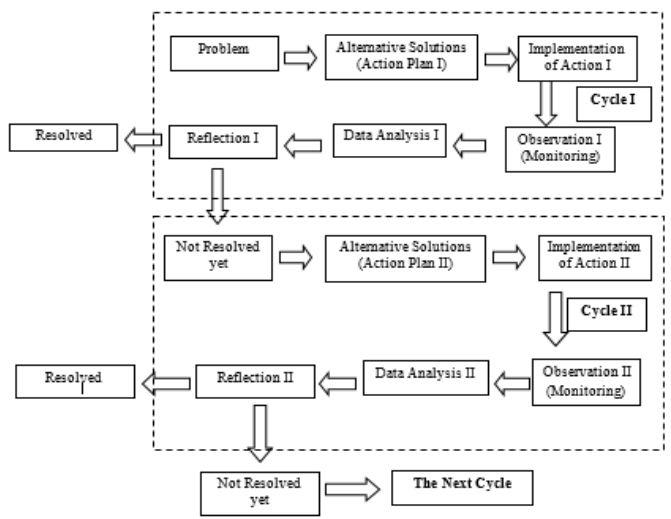

Fig. 2. Classroom Action Research Path 


\section{Result And Discussion}

Before researching in the field students had learned statistics about the data center, the location of the data and the found of students' difficulties when processing the final grades and there were several factors that cause this to be based on the results of student worked.

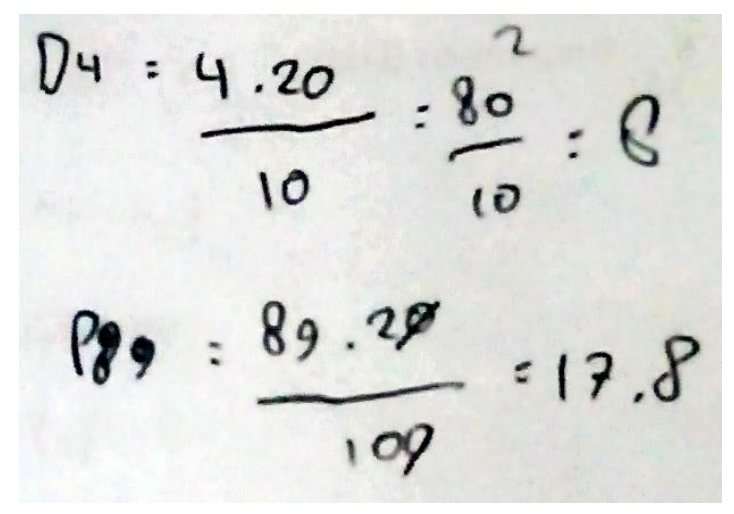

Fig. 3. Students 'errors about the location of the data

Figure 3 shows the students' errors when worked on deciles and percentiles, students only understood the relationship of understanding the location of the data with the divider that is if the decile is divided by 10 and if the percentile is divided by 100, but students do not give the results of the data sequence from the data that had been sorted. Difficulties of students, did not understand the connection between the layout of data and value data.

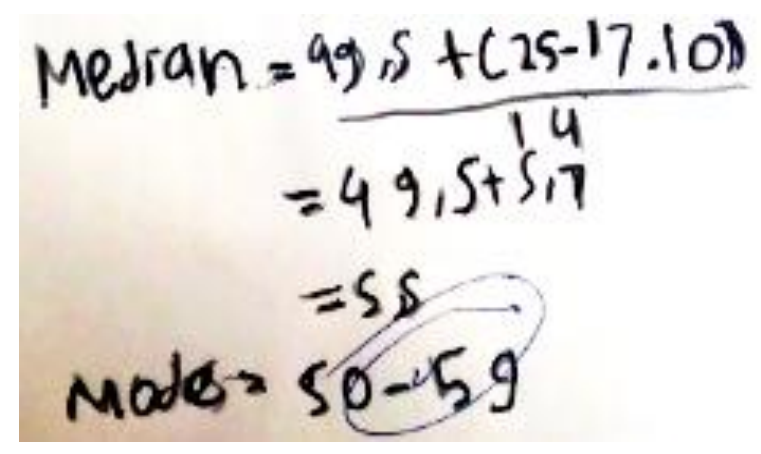

Fig. 4. Students 'errors about Median and Mode

Figure 4 shows the students' errors when completed the median results of group data by writing the calculation operation incorrectly and determining the results of the mode for group data to only write mode class evaluations that have the highest frequency. This, the difficulty of students not being able to understood how to write number operations and not yet able to 
process from the initial stage to the results stage. In line with Baumert's opinion [17], students' mistakes in the process of learning mathematics are fundamental operations of numbers, patterns or functions, and algebra

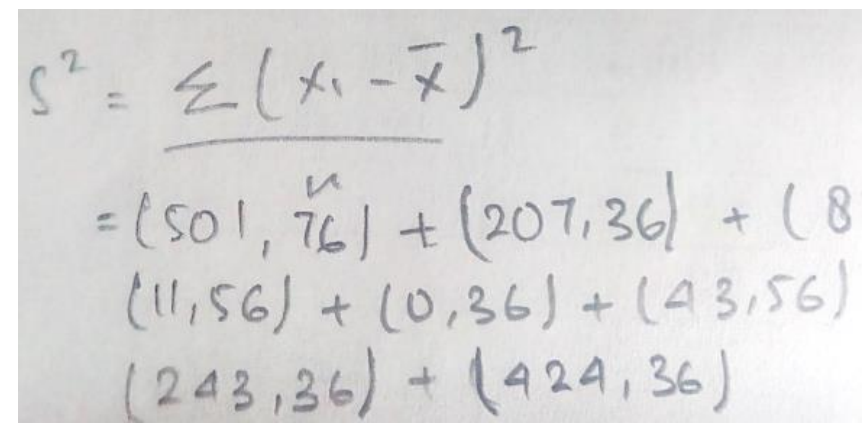

Fig. 5. Errors of students working on Variants

Figure 5 shows students' errors used the inconsistency formula when there were many value divisors, and this often happens to students who worked on variance, i.e. accuracy caused students to be wrong in results, and students did not complete their work. The mistake people use because there are careless people when working on the problem [18].

Of the three images was one of the five questions from the essay questions given by students which often occured errors in the worked process and the students' difficulties that could not be answer and could not explain the reason.

Table 1. Mastery of Statistical Material Before Learning

\begin{tabular}{clcc}
\hline No & \multicolumn{1}{c}{ Problem } & Many Student & Percentage \\
\hline 1 & Single Data (Data Center) & 25 & $71.39 \%$ \\
2 & Single Data (Location Data) & 13 & $37.78 \%$ \\
3 & Group Data (Data Center) & 11 & 31.67 \\
4 & Group Data (Data Layout) & 9 & 26.57 \\
5 & Single Data Spread (Average Deviation) & 5 & $15 \%$ \\
6 & Single Data Spread (Variant) & 3 & $10.28 \%$ \\
7 & Single Data Spread (Standard Deviation) & 4 & $12.5 \%$ \\
\hline
\end{tabular}

Table 1 explains, students had mastered the data center consisting of average values, media and mode for single data because students already understood the prerequisites in junior high school, while mastery of the data layout formula for new students understood the process of using formulas quartile, decile and single data percentile while what they understood was a process without process. While students lack control of the center and location of group data because they did not understand the key to got results from the formula used. Likewise, the same thing, for the distribution of data difficulties encountered were about mathematical symbols related to using the data distribution formula. 
Table 2. Students Prior Learning Ability Mastery

\begin{tabular}{clcc}
\hline No. & \multicolumn{1}{c}{ Mastery } & Many Student & Percentage \\
\hline 1 & Using Formulas & 15 & $41.67 \%$ \\
2 & How to use step & 14 & $38.33 \%$ \\
3 & Use number operations & 24 & $65.83 \%$ \\
4 & Complete & 11 & $29.44 \%$ \\
\hline
\end{tabular}

In Table 2, showed that the mastery of the use number operations and use the formula quite a lot, and needs to be increased again. But what needs to be given was the way students could achieve completeness. In the completeness factor, the most number of students means that there are many problems that were not work out or students worked halfway.

From the results of data analysis, several factors in table 2 could be taken into consideration to made a mathematics learning strategy plan in the preparation stage, namely making ICT-based mathematics learning media, namely VBA software for Microsoft Excel.

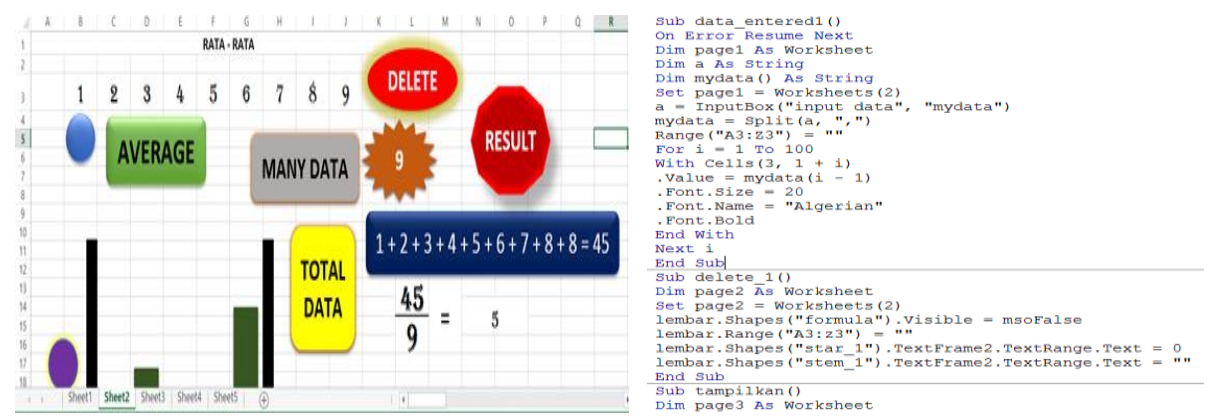

Fig. 6. Making a game of average values

Figure 6 shows the average game of single data values using VBA for Microsoft Excel by using pictures on shapes, where each bar has a different function when pressed, and students will answer the purpose students will understand the last average is associated with the formula.
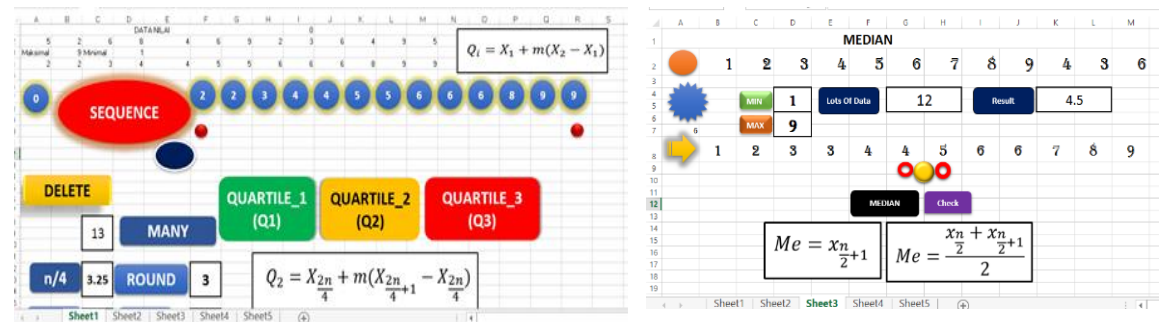

Fig. 7. Location of data and Median

Figure 7 shows the making of games about the location of data, after the mean values such as median, quartile, decile and percentile for single data.
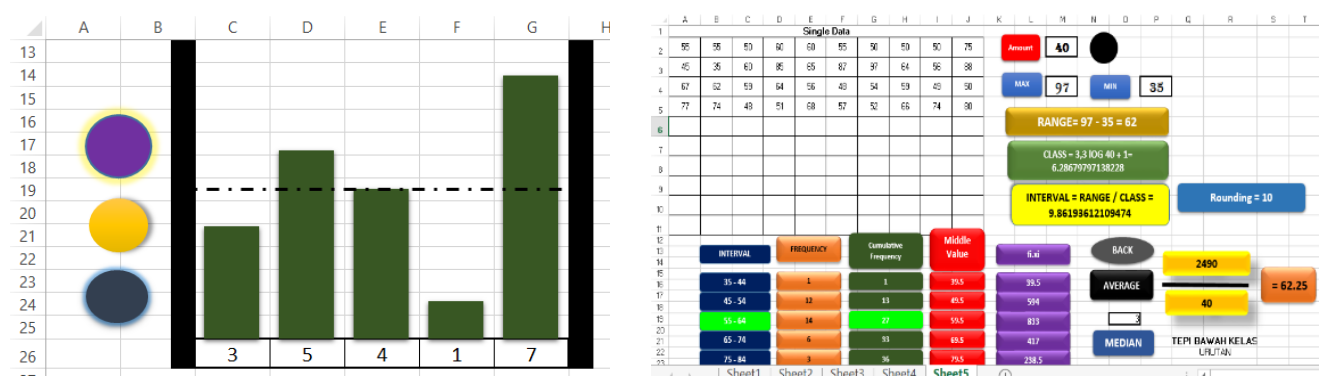


\begin{tabular}{llll}
\hline No & Problem & Many Student & Percentage \\
\hline
\end{tabular}

Fig. 8. Standard deviations and group data

Figure 8 shows the game about standard deviations and group data for data centering, data location and data dissemination, students could explore in different data as an exercise for students to understand statistical calculations as implementation stages in class.
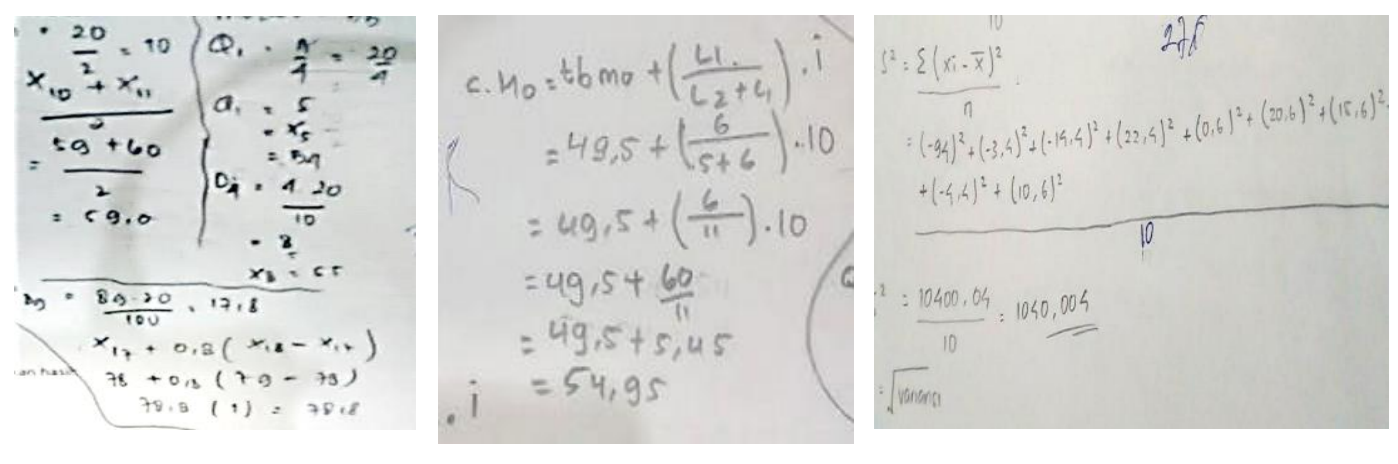

Fig. 9. Student Outcomes

From the results of students, shown in Figure 9, after students conducted cycle 1 and cycle 2 with Excel VBA for Microsft ICT found students had understood the calculation steps associated with formulas and most of them had completed solving statistical questions given to students; this could be seen from the results of students' abilities. And from the students' scores obtained when the average before doing the experiment was 41.80 with a standard deviation of 1.81 and after experimenting, it was obtained an average value of 64.68 with a standard deviation of 2.41. Both data were processed using SPSS 22, namely the normality test obtained by the significant value of both data, ie before the experiment 0.17 and for after the experiment 0.20 means that the two significant values $>0.05$, concluded that the two data was normal then continued with the test $t$ pair with a significant value of $0.000<0.05$ means that learning after the experiment was better with the previous one and a significant correlation value of 0.569 means that there was an influence of shapess games through VBA for Microsoft Excel in learning statistics. These results indicated the existence of learning using ICT before and after [19], [20].

Table 3. Mastery of Statistical Material After Learning 


\begin{tabular}{llcc}
\hline 1 & Single Data (Data Center) & 35 & $96.39 \%$ \\
2 & Single Data (Location Data) & 25 & $68.89 \%$ \\
3 & Group Data (Data Center) & 27.5 & $76.39 \%$ \\
4 & Group Data (Data Layout) & 19 & $51.67 \%$ \\
5 & Single Data Spread (Average Deviation) & 11 & $30.56 \%$ \\
6 & Single Data Spread (Variant) & 16 & $44.72 \%$ \\
7 & Single Data Spread (Standard Deviation) & 17 & $47.5 \%$ \\
\hline
\end{tabular}

Table 3, shows the results of mastering the statistical material in increasing number of students especially understanding Data dissemination and for single data students have increased to more than $50 \%$, which means that most of them already understand the center and location of data both single data and group data.

Table 4. Ability Mastery Students Having Learning

\begin{tabular}{clcc}
\hline No. & \multicolumn{1}{c}{ Mastery } & Rate & Percentage \\
\hline 1 & Using Formulas & 25.3 & $70.28 \%$ \\
2 & How to use step & 29.4 & $81.67 \%$ \\
3 & Uses number & 32.8 & $91.11 \%$ \\
4 & operations & 24.3 & $67.5 \%$ \\
\hline
\end{tabular}

For the ability of students in Table 4 explains that most of the students entirely in for $60 \%$ of students' ability to understand statistics.

Table 5. Quetionnare on Student Confidence

\begin{tabular}{clcc}
\hline No & \multicolumn{1}{c}{ Questionnaire Items } & Many Students & Percentage \\
\hline 1 & $\begin{array}{l}\text { Finding information on their own to look } \\
\text { for statistical formulas } \\
\text { There is a desire to work ahead of class } \\
\text { when the teacher asks questions }\end{array}$ & 24 & $66.67 \%$ \\
3 & $\begin{array}{l}\text { Shame Answering when making a } \\
\text { mistake }\end{array}$ & 16 & $80.56 \%$ \\
4 & $\begin{array}{l}\text { Active ask when there is a statistical not } \\
\text { understood } \\
\text { Cannot do the problem, if the teacher } \\
\text { explains the material }\end{array}$ & 31 & $44.45 \%$ \\
\hline
\end{tabular}

Table 5 describes the positive relationship with information about using statistics using VBA for Microsoft Excel. By using VBA for Microsoft Excel as a mathematics learning medium that can be used to solve problems [21]. 


\section{Conclusion}

From the results of the study, that VBA for Microsoft Excel can help teachers to make statistical learning strategies in the form of media, and also can benefit for students to develop students' mathematical understanding and confidence skills.

\section{Aknowledgment}

The author would like to thank the Siliwangi Teacher Science and Education School and Kartika XIX - 1 Bandung Middle School for helping the Lecturer to School Assignment process as a grant program from the Ministry of Research, Technology and Higher Education. and thank you to the directorate of learning and student affairs at kemenristekdikti who have funded the PDS program at IKIP siliwangi

\section{References}

[1] M. Bernard, "Meningkatkan Kemampuan Komunikasi dan Penalaran Serta Disposisi Matematik Siswa SMK dengan Pendekatan Kontekstual Melalui Game Adobe Flash CS 4.0," J. Ilm. Progr. Stud. Mat. STKIP Siliwangi Bandung, vol. 4, no. 2, pp. 197-222, 2015.

[2] T. Koparan, "Difficulties in learning and teaching statistics: teacher views," Int. J. Math. Educ. Sci. Technol., vol. 46, no. 1, pp. 94-104, 2015.

[3] S. Hartati, I. Abdullah, and S. Haji, "PENGARUH KEMAMPUAN PEMAHAMAN KONSEP, KEMAMPUAN KOMUNIKASI DAN KONEKSI TERHADAP KEMAMPUAN PEMECAHAN MASALAH," J. Math. Educ. Sci. Technol., vol. 2, no. 1, pp. 43-72, 2017.

[4] R. Amelia, W. Susilawati, A. H. Syaf, R. L. Ariany, and S. Supian, "Application of accelerated learning method to improve the ability of students ' mathematical representation,” World Sci. News An Int. Sci. J., vol. 101, no. June, pp. 65-76, 2018.

[5] M. R. Ramdhani, B. Usodo, S. Subanti, J. W. C. Lee, and A. Tanusia, "Student' s mathematical understanding ability based on self-efficacy Student 's mathematical understanding ability based on self- efficacy," J. Phys. Conf. Ser. 909 012065, vol. 909, no. 012065, pp. 1-8, 2017.

[6] N. Hashemi, M. Abu, S, H. Kashefi, and K. Rahimi, "Undergraduate Students' Difficulties in Conceptual Understanding of Derivation," Procedia - Soc. Behav. Sci., vol. 143, pp. 358-366, 2014.

[7] H. Le, J. Janssen, and T. Wubbels, "Collaborative learning practices: teacher and student perceived obstacles to effective student collaboration," Cambridge J. Educ., vol. 48, no. 1, pp. 103-122, 2018.

[8] W. Setyaningrum and N. H. Waryanto, "Developing mathematics edutainment media for Android based on students' understanding and interest: A teachers' review," J. Phys. Conf. Ser. 983 012093, vol. 983, no. 1, 2018.

[9] M. Bernard, E. D. Minarti, and M. Hutajulu, "Constructing Student's Mathematical Understanding Skills and Self Confidence : Math Game with Visual Basic Application for Microsoft Excel in Learning Phytagoras at Junior High School,’ Int. J. Eng. Technol., vol. 7, no. 3.2, pp. 732-736, 2018.

[10] M. Bernard, "PENGARUH PEMBELAJARAN DENGAN MENGGUNAKAN 
MULTIMEDIA MACROMEDIA FALSH TERHADAP KEMAMPUAN PENALARAN MATEMATIK," Pros. Semin. Nas. Pendidik. Mat. STKIP Siliwangi, vol. 1, pp. 425-429, 2014.

[11] M. Bernard and S. Chotimah, "Improve student mathematical reasoning ability with open-ended approach using VBA for powerpoint," AIP Conf. Proc., vol. 020013, 2018.

[12] S. Chotimah, M. Bernard, and S. M. Wulandari, "Contextual approach using VBA learning media to improve students ' mathematical displacement and disposition ability Contextual approach using VBA learning media to improve students mathematical displacement and disposition ability," J. Phys. Conf. Ser. 948 012025, 2018.

[13] David M. Marcovits, Powerfull Powerpoiint For Educators, 2nd ed. Santabarbara, California: Libraries Unlimited, 2012.

[14] E. Senjayawati and M. Bernard, "PENERAPAN MODEL SEARCH - SOLVE CREATE - SHARE UNTUK MENGEMBANGKAN KEMAMPUAN PENALARAN BERBANTUAN SOFWARE GEOGEBRA 4.4," MAJU, vol. 5, no. 1, pp. 66-78, 2018.

[15] G. Singh and K. J. Siddiqui, "Microsoft Excel Software Usage for Teaching Science and Engineering Curriculum Microsoft Excel Software Usage for Teaching Science and Engineering Curriculum *,” J. Educ. Technol. Syst. Spring, no. January, pp. 1-10, 2008.

[16] R. Kemmis, S dan McTaggart, The Action Research Planner, 3rd edn. Victoria, 1988.

[17] J. Baumert et al., "Teachers' Mathematical Knowledge, Cognitive Activation in the Classroom, and Student Progress,” Am. Educ. Res. J., vol. 47, no. 1, pp. 133-180, 2010.

[18] E. Zakaria and C. Author, "Analysis of Students ' Error in Learning of Quadratic Equations," Int. Educ. Stud., vol. 3, no. 3, pp. 105-110, 2010.

[19] I. Rajendra, M and I. Sudana, M, "The Influence of Interactive Multimedia Technology to Enhance Achievement Students on Practice Skills in Mechanical Technology The Influence of Interactive Multimedia Technology to Enhance Achievement Students on Practice Skills in Mechanical Technology," J. Phys. Conf. Ser., vol. 953, no. $012104,2018$.

[20] S. H. Halili and H. Sulaiman, "Factors influencing the rural students' acceptance of using ICT for educational purposes," Kasetsart J. Soc. Sci., pp. 1-6, 2018.

[21] X. Muianga, T. Klomsri, and M. Tedre, "From Teacher-Oriented to Student-Centred Learning: Developing an ICT-Supported Learning Approach at the Eduardo Mondlane University , Mozambique," Turkish Online J. Educ. Technol., vol. 17, no. 2, pp. 46-54, 2018. 